\title{
THE EFFECTIVE USAGE OF SOCIAL MEDIA FOR EMPLOYER BRANDING
}

\section{DR. SASMITA MISRA}

Assistant Professor, NMIMS, Hyderabad, India

\begin{abstract}
In the break of the new century, we see several challenges that the new talent acquisition manager is confronted with. Demographic changes and war for talent has shifted the focus of the organization from financial goals to people centric goals. Building a stronger organization required the people at the top to think strategically to meet the gap between the demands for a certain category of talent to supply in the required category. Even top-notch companies like Google and Amazon today are confronted with the challenge of meeting the talent needs of the organization. The innovative acquisition practices are developed to not only attract the smarter candidates but also to create a brand for themselves in the market. The challenges which most companies are facing today are not only attracting the best candidate to apply for the vacant post but also finding the best fit for the organization. This dynamic has led to a lot of frustration from the talent acquisition managers. In this present scenario, what came as a boon to most of the talent acquisition managers is the usage of social media for recruiting and hiring the top talent.

The millennial generation (or "digital natives") grew up with social and mobile technology and led the way in adopting these technologies. But today, job hunters across demographic groups often begin their interactions with employers via the social Web, where they expect to become familiar with the employer's culture and "brand," learn about available job opportunities and even directly engage with employers.

The purpose of the research is to understand the effective usage of social media for attracting and retaining employees in the industry and also to evolve strategies to create a compelling brand. Social media has proved to be faster in reaching out to the millennials but the biggest drawback which was observed by many of the industry stalwarts today is to find the best fit for the vacant positions over a period of time. The media has also opened up several challenges like employees have started moving from one job to another which creates a vacuum in most of the organizations in their key positions and there is increased competition for retaining the employees. For the purpose of the study, a comparative analysis is drawn between various companies to understand how each competing brand have fared in branding themselves through social media.
\end{abstract}

KEYWORDS: Employer Branding \& Social Media

Received: Aug 07, 2021; Accepted: Aug 27, 2021; Published: Sep 09, 2021; Paper Id.: IJHRMRDEC20218

\section{INTRODUCTION}

In the $21^{\text {st }}$ century where we find the digital natives joining the corporate world- it has become imperative for the organization to use social media sites like LinkedIn, Facebook and Twitter. This shift in technology has been the norm for every organization in today's context to hire and retain the best talent from the industry. As observed by Peter cheese (2007) that the biggest challenge of any leader in the present scenario is to attract and retain the top talent in their organization. The rapid shift in technology has also enabled the job seekers to explore a wider array of companies in their area and develop their professional network and also to assess the culture of the company in general to understand the perception of the employees who are currently working in the organization. 
The war for talent can no longer be dismissed as just another management cliché despite global economy downturns (Linda Holbeche 2009). Recruitment till date has been one of the integral parts of many organizations. At the same time organizations have been very keen on working consciously towards improving their brand image so that they can create a compelling image in the eyes of the employees. Hiring is a process of employing new staff to engage the services of a person for wages. (Mandy and NOE 2008) state that recruitment is the process of attracting potential talent in the industry. The same is the case with the job seekers who are continuously on the hunt to find the best company which can not only provide them with a good working culture but also provide them with the required career growth so that they can put their career on the fast track.

Social media has been the platform in the $21^{\text {st }}$ century where the transaction between the employer and employee is done in a fruitful way to get engaged and build genuine relationships. (Narvey 2009) Social media recruitment (SMR) refers to recruitment with the help of social media sites like Facebook, Twitter and Linked In.

Employer branding is a process of building or managing and influencing the organization's reputation as an employer among job seekers. It encompasses everything you do to position your company's image as an employer of choice. For this, every organization works on the three aspects that are their corporate strategy regarding people and then followed by best HR practices and a good communication strategy to the prospective employees. Therefore everything about branding starts with how your present employees perceive the company. Your reputation as an employer exists in the minds of the employees as to how you treat them and you have crafted the employee value proposition. Employer branding strategy can be one of the competitive strategies for any organization. Employers who use LinkedIn and Facebook have the highest potential of reaching young potential professionals in the workplace. (Schroeder, 2010). Linked In is used for business and networking reasons and can be used to describe a virtual contact book (Bulik, 2008). With the advancement of technology, both the employer and employees use this platform to express their value propositions and use it to create a compelling brand for themselves.

\section{OBJECTIVE OF THE STUDY}

- To understand the various strategies companies use to be the employer of choice.

- $\quad$ To understand the usage of social media to create a compelling brand.

\section{Strategies to be Employer of Choice}

To be the employer of choice has been one of the major thrust areas of the organization. It has become imperative for organizations to strengthen their brand image and create a strong relationship not only with their existing employees but also with the new employees. Creating a successful employer brand leads to attracting the best talent in the organization and also it retains the existing employees by creating a strong social presence. Employer branding refers to the deliberate and unique strategy of creating perceptions about the organization as an employer, its culture and values. In the minds of the stake holders, current and potential employees of the organization. Research has indicated that an organization having a strong employer brand will have a strong influence on the decision of potential employees seeking to pursue good opportunities (Hans and Collins, 2002) Additionally, it has also been suggested that applicants react positively to elaborate descriptions emphasizing positive attributes of an organization (Backhaus, 2004). Therefore the stronger the employer brand of an organization the larger the pool of applicants and potential hires. Organizations thus pay a lot of attention to craft a distinct and well-defined employer brand. 
Research indicates that there are three ways in which an employer brand is created in real-time. First, it should focus on what it communicates to the corporate world, second, it should focus on building the culture of the organization so that the existing employees can be its brand ambassador and will act as referrals for the organization. Thirdly the organization's strategy plays a major role in communicating the organization's mission and vision to the employment market,

For the communication strategy of the employer brand, employers should focus on a compelling value proposition to their employees. Some of the compelling employee value propositions are listed as follows:

- Social Responsibility: The millennials get attracted to the organization which has made its social presence by contributing to the good of the society like the Tata group in India. By being socially conscious or donating to various causes of society the organization is able to create a positive meaning to society. Like Dr Reddy's Foundation has a special department dedicated to the cause of uplifting society. They encourage young minds to participate in their social causes through various projects thereby encouraging and exposing the millennials to the work culture of the organization,

- Career Advancement: to encourage workers to stay in the organization it is imperative that they experience growth in their careers. Workers should be exposed to a visible career ladder in the organization. Having a clearly communicated ladder shows employees that there is something to work towards giving them a sense of a future with the company. With a clear visible career path employees can be motivated to continuously learn and grow in the organization. It also enhances their skill and this will help them to be engaged and satisfied with the organization.

- Recognition: This is another biggest employee value proposition. Employees put a lot of effort at work and as an employer of choice, an organization should reward them appropriately. Setting goals is another way of engaging the employees and when employees contribute to these goals they feel the impact they created for the organization.

- Compensation: employees like to work for organizations which compensate them fairly as per market standards. Also, employees feel that the employee benefits package, including health insurance, paid holidays, time off and vacation has been the top benefits the employees prioritize in their compensation packages.

Asch provided six "principles for excellence" that employers can adopt to become an employer of choice.

- Use your words wisely. It is important to communicate with employees with honesty, openness, and respect. Communications should focus on what is possible.

- be accountable. Employers should act proactively and be committed to truth telling, focusing on the question behind the question rather than offering excuses or explanations.

- Focus. By focusing on independent goals, employers can extract the greatest value from the efforts of employees.

- Mine the gold. Employees and managers should strive to bring out the best in their employees, and be committed to collaboration and cooperation.

- Strive for balance. Employees will be vital and energetic at work as a result of a balanced life. Employers should 
therefore give their employees the opportunity to refresh and renew.

- Lighten up. Perhaps the most difficult of the six principles, employees should not take themselves so seriously. Employers and their employees should seek to bring laughter and joy to the workplace and look for opportunities to make other people's day.

Asch stressed that these principles must be adopted by everyone in the organization from the top down. The model is designed to create new habits and a fresh mindset in a system that is peer enforced and led by enlightened leaders, transforming an organization into an employer of choice and allowing employers to attract and retain top talent.

When developing employer branding it is important for an organization to consider the following:

1. What are the strongest, most attractive and compelling attributes of the organization to both current and potential employees?

- Which are the critical roles within the companies and how will the organization acquire and retain talent for these roles?

- What are the competencies and attributes of the current talent pool as well as their future requirements?

- What do the current employees perceive about the organizational culture

- How aligned is the current employer brand with the external brand of the organization.

With the above information, an organization can get an understanding of where it is currently and what steps need to be taken to evolve an effective employer brand. This leads to the crafting of brand strategy. While the responsibility of the brand lies with the HR, Internal communications and marketing departments, every employee in the organization contributes towards living the employer brand.

\section{Usage of Social Media to Create a Compelling Employer Brand}

Social media is great news for businesses and brands and the best part is, both big and small brands can benefit. When organizations know the figures, it's easy to understand why business and consumer marketers almost unanimously believe that social media is crucial to building a brand. So, when it comes to social media branding, it's important to invest some thought and resources into it.

- According to a 2020 report, social media users have passed the 3.8 billion mark. It is definitely very encouraging for companies because this gives a better reach to the organization.

- $\quad 80 \%$ of employees, as well as consumers, are more likely to evaluate solutions from the brands they follow on social channels.

Brand awareness is cited as the top priority for employers, and social media channels are a one-to-many solution for getting the word out about your products and services. By creating a strong brand presence on social media, you can reach a broader audience.

In social media employer branding has played a major role in attracting and also from the best of the competing organization. Schwab's helpful guide on finding your brand voice lays out several factors:

Tone. Be clear to followers about what and how the brand will communicate online. Is your brand cheeky and 
irreverent or serious and formal?

Language. What type of language will your brand use online? A young and hip brand might get away with more slang, or a niche brand may use more acronyms and industry-specific language.

Purpose. Identify the main reason the brand is on social media? Is your goal to educate or entertain?

Finally, put together a social media style guide that outlines your tone of voice. It will be a useful reference document for anyone in the company who speaks on behalf of a brand.

The social media platforms used to create a compelling brand are as follows:

\section{Digital Media}

Job portals, LinkedIn, glass door etc. have been the most promising platforms to track prospective employees and to understand how they perceive an organization's brand. In these platforms it is imperative to follow the following methods to make them more attractive and engaging:

- Talk like a human being: When it comes to social media, the method that has proved successful over time is to talk like a human being. Ditch the corporate speak and take a conversational approach. Respond to inquiries on a first-name basis, and don't be afraid to use colloquial dialogue. Talking like a human being with personality will make a brand more relatable. And if it's really clever, genuine, and entertaining it may even go viral.

- Quit plugging, start conversing: Along those same lines, focus on building a two-sided relationship with employees by conversing, interacting, and caring. Don't solely plug products or services. Genuine, two-way communication is key because, at the end of the day, people need to inherently trust a brand that values them.

- Tell a compelling story: Who doesn't love a good story? Storytelling is central to human existence. In fact, telling someone a story can have the powerful effect of getting them on board, as it causes the listener to turn the story into their own idea and experience. In the same way, a brand — or the idea of a brand - can become more compelling by spinning a yarn about it. Involve customers in a brand story and they will engage.

- Be transparent: Transparency is the bedrock of any long-lasting relationship, so in the same way, giving customers a glimpse behind the scenes can prove vital in establishing a healthy relationship.

- Post relevant content: Don't post for the sake of posting. Keep social media posts relevant, meaningful, and simple. 'Boring' content is one of the main reasons people will unfollow and unlike brands.

- Make it visual: Users engage with posts that include images, more than with posts that don't include them. Add infographics, photographs, and other visual images, taking advantage of Pinterest and Tumblr, which can be used to store and share visual content.

\section{Social medi}

Facebook, quora and Instagram etc. also can be tapped to showcase how the organization is transparent in many of the issues related to their initiatives and also to showcase the achievements of their stakeholders. Organizations can use these mediums to emotionally attach the employees to the brand. Employees start taking pride in seeing the number of followers for a specific brand image the companies create on the social platform. Various organizations like L'Oréal create engaging 
content and events which pull prospective job seekers to participate in such events and get a feel of the organization.

\section{Employee Ambassadors}

experience built around the workplace also empowers people to perform. Employees create blogs of their own to share their experiences about the various practices of the organization and that acts as attractive points for the employer. Even doorstep or email aspirants experience a difference in the whole attempt to join and new hires have enough and more to talk about and absorb around the workplace.

\section{CONCLUSIONS}

Social media can be a great tool to increase your online presence, but as more brands jump on the bandwagon, marketing clutter can make it hard to compete. Organizations should be sure to not only use social media as a branding tool but to effectively stand out and keep employers and customers engaged and interested. The rise of social media usage as a branding tool has gained prominence in small as well as big companies. As an employer brand grows and develops over time it requires continuous attention. The best employer brands are careful about monitoring the ever-changing needs of their talent and adapt to shifts in their workforce. Accordingly, conducting employee satisfaction surveys, organizational climate and culture surveys, employee workshops and exit interviews enable an organization to receive information and insight into the employer brand.

\section{REFERENCES}

1. Abel S, 2011; The role of social networking sites in recruitment: Results of a Quantitative Study among German companies, 12 April 2013).

2. Bartram. D, (2000) Internet recruitment and selection: Kissing frogs to find princess, International journal of selection and Assessment, 8(4): 261-74

3. Breagh, J.A and Starke, M. (2000) Research on employee recruitment: so many studies and so many remaining questions, Journal of Management, 26(3): 405-34

4. Cascio,w and Boudreau, J (2008) investing in people: financial impact of Human resources Initiatives. New Jersey: FT Press.

5. Clark LA, \& Roberts SJ, 2010; Employers use of social networking sites: A socially irresponsible practice, Journal of Business Ethics, Vol. 95, pp. 507-525.

6. Deloitte research (2004) its 2008: do you know where your talent is? A Deloitte study.

7. Dickie C \& Dwyer J, 2011; A 2009 perspective of HR practices, Journal of Management Development, Vol. 30, No. 4, pp. 329-343.

8. Holbeche, L (1998) High flyers and succession planning.

9. Matthews, V(2007) personnel today, 22nd May 2007

10. Mondy, R.W., And Noe, R.M., (2008), Human Resource Management, 10th Edition, New Jersey, Prentice-Hall

11. http://www.quepublishing.com/articles/article.aspx?p=1829424 (Carter B, 2012; Facebook versus LinkedIn for professional networking, 25 September 2013).

12. https://hr.blr.com/whitepapers/HR-Administration/HR-Strategic-Planning/Six-Principles-for-Becoming-an-Employer-ofChoice 
13. Sharma, Garima. "A Critical Study of the Biology Curriculum at Senior Secondary Stage With Respect to Life Skills Education and the HIV/AIDS Education." IASET: International Journal of Library \& Educational Science (IASET: IJLES) 2.3 (2016): 110.

14. Dhevika, VPT, and OTV Latasri. "A Study on Quality of Work Life among Working Women in Tiruchirappalli District." IASET: Journal of Humanities and Social Sciences (IASET: JHSS) Vol. 2, Issue 2, Jul - Dec 2016; 5-16 
